\title{
SOME STUDIES OF POSTERIOR PITUITARY AND ADRENAL CORTICAL INTERRELATIONSHIPS IN PATIENTS WITH AND WITHOUT CIRRHOSIS OF THE LIVER ${ }^{1,2}$
}

\author{
BY J. F. HARRIS, C. W. LLOYD, AND J. LOBOTSKY \\ (From the Departments of Medicine and Obstetrics, State University of New York, \\ Medical College, Syracuse, N. Y.)
}

(Submitted for publication March 16, 1953; accepted April 7, 1953)

It is well recognized that both the adrenal cortical and posterior pituitary hormones play an important part in the regulation of salt and water metabolism (1). Antagonistic relations between these two hormones have been postulated (2). It has also been shown that in the human a reciprocal relationship exists between the antidiuretic activity of serum and the corticosteroid of urine (3). During diuresis, the antidiuretic activity in serum is low and the corticosteroid excretion in urine is high, whereas, during water retention, the converse situation is found.

Increased amounts of antidiuretic material were recovered from patients with active cirrhosis of the liver by Ralli, Robson, Clarke, and Hoagland (4). In the experimental animal, the liver has been found to be the most effective site of inactivation of the posterior pituitary hormone $(5,6$, 7 ). It was decided, therefore, to study the effects in patients with liver disease of artificially elevating the levels of circulating antidiuretic material by the administration of posterior pituitary extract.

This report is concerned with: a) the changes in metabolism of water and sodium resulting from repeated administration of pitressin tannate in oil, and b) the relationship between plasma sodium and urinary excretion of corticosteroid. The response to exogenous adrenal cortical steroids given concomitantly with posterior pituitary extract was also studied.

\section{METHODS}

The studies of the response to pitressin tannate injected daily have been carried out on five patients with Laennec's cirrhosis and on five "control" patients recovering from

1 This paper was read in part before the American Society for Clinical Investigation in May, 1951.

2 This work was in part supported by grants from the Ciba Company and the Upjohn Company. The pitressin tannate used was supplied through the courtesy of Dr. D. various diseases, but without evidence of Laennec's cirrhosis. In addition, one patient (Case 11), a confirmed alcoholic with history of phosphorus poisoning as a child, but with no laboratory evidence of cirrhosis, was studied. $\mathrm{He}$ was under treatment for erythromelalgia following frost-bite. Further study, reported under Case 11 in the Appendix, provided evidence of some degree of adrenal insufficiency. For these reasons the patient could be considered neither as a control patient nor a patient with liver disease.

All of the cirrhotics had had ascites, but at the time of the studies only one patient was in positive water balance. The subjects were maintained on a controlled diet of known sodium content and five $\mathrm{Gm}$. of salt in solution was given in addition each day. Fluid intake was maintained at a constant level for each patient, usually 2,500 cc. each day. Measurements of weight, urine volume, and urine sodium and potassium were made daily. Frequent determinations of plasma sodium and potassium were obtained by means of the flame photometer. Urinary corticosteroid was measured by a method which has been previously described (8). The normal values range from .200 to $.750 \mathrm{mg}$. of corticosteroid per 24 hours. Pitressin tannate was administered intramuscularly in oil in a dose of $\mathbf{5}$ units once daily for approximately the first week of the experiment. In several cases, when no effect upon water or electrolyte excretion was observed, the dose was increased to ten or more units daily in two divided doses. When the administration of pitressin tannate had caused significant water retention and depletion of plasma sodium levels, adrenal cortical extract, i.e., lipo-adrenal cortex (Upjohn) intramuscularly, aqueous cortical extract (Upjohn) intravenously, was given while the pitressin tannate injections were continued. The course in each patient is reported separately in the Appendix.

\section{RESULTS}

\section{The Effect of Continued Administration of Pi- tressin Tannate upon Water and Sodium Bal- ance}

Injection of pitressin tannate resulted in weight gain from water retention in all patients, but of varying degree.

\footnotetext{
A. McGinty of Parke, Davis \& Company. The adrenal cortical extract and lipo-adrenal cortex was supplied by Dr. H. F. Hailman of the Upjohn Company.
} 
For the purpose of comparison, Cases 1-5 (see Appendix) are reported together as control patients and Cases 6-10 are reported as cirrhotic patients. Case 11 is reported separately.

Figure 1 records the weight changes of the cirrhotic and control patients up through the seventh day of the study (fourth day of pitressin administration). Both groups received 5 units of pitression. tannate in oil intramuscularly daily. After the seventh day of the study, the sensitivity responses were not entirely comparable since pitressin dosage was increased in several cases. Some subjects were given adrenal cortical hormone after this date and were, therefore, not included in the graph after such administration.

By the fourth day of the administration of five units of pitressin tannate daily intramuscularly, the cirrhotic group had an average weight gain of 6.4 lbs., a maximum of 13 lbs. Control subjects gained an average of $2.9 \mathrm{lbs}$. The maximum was 7 lbs. of fluid retained. There is considerable spread in the weight gains recorded for individual subjects. The one cirrhotic who did not gain weight failed to do so because of severe vomiting.

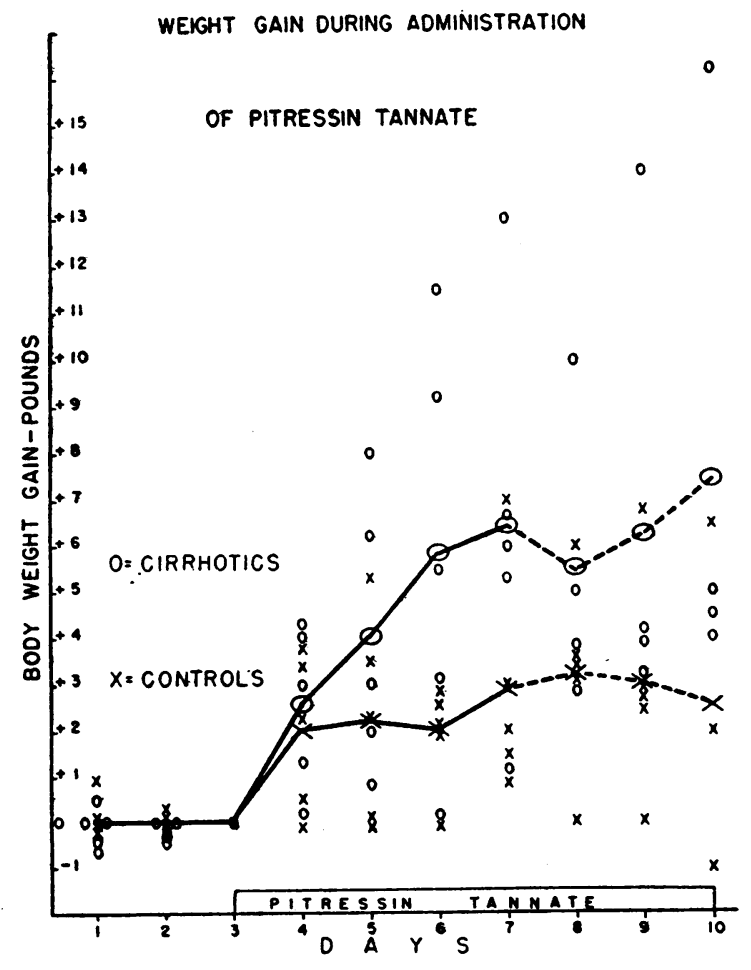

FIG. 1.
PLASMA SODHM ChaNGe DURING DAILY ADMNISTRATION OF PITRESSIN TANNATE

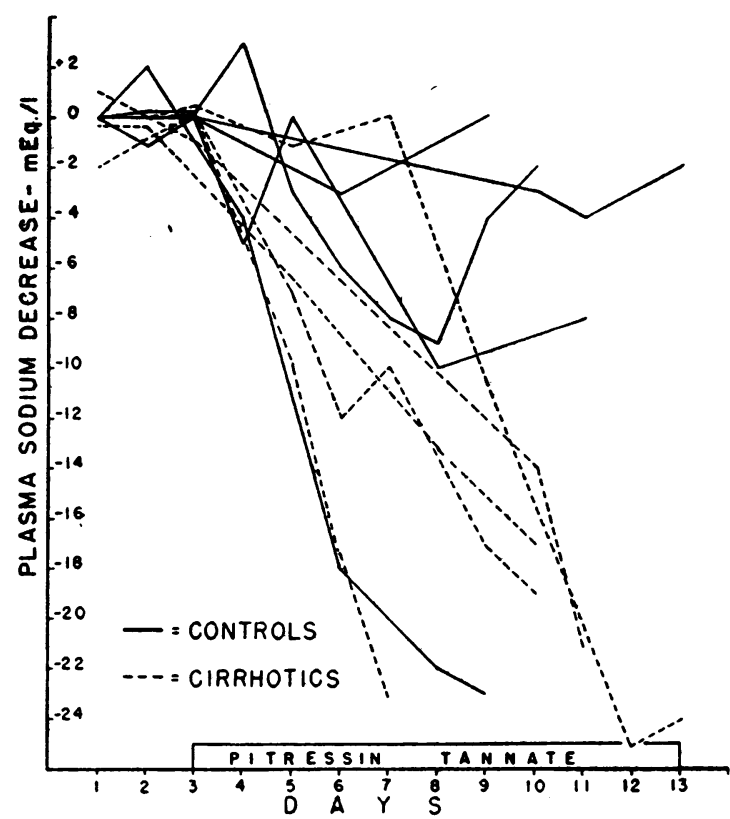

FIG. 2.

The remaining cirrhotics all gained more than five pounds and the amount of fluid lost as vomitus by the fifth cirrhotic was considerably more than five pounds. One of the control subjects had a weight gain comparable to the average of the cirrhotics. None of the remaining control patients gained more than three pounds of weight. For these reasons, it is felt that although the groups are too small to permit positive proof of statistical significance of the differences in the groups, the data suggest a definite trend for the cirrhotic group to gain more weight than the control group.

Continued administration of pitressin tannate also produced a decrease in plasma sodium in both groups. Figure 2 compares the degree of response in the two groups during this part of the study. The cirrhotic patients responded with a dramatic drop in plasma sodium levels ranging between 17 and $25 \mathrm{mEq}$. per liter. Only one control patient (Case 5) evidenced a comparable plasma sodium decrease. The remaining four control subjects responded with only a moderate hyponatremia of 2 to $10 \mathrm{mEq}$. per liter. The plasma sodium levels could not be well correlated with water retention and weight gain in all in- 


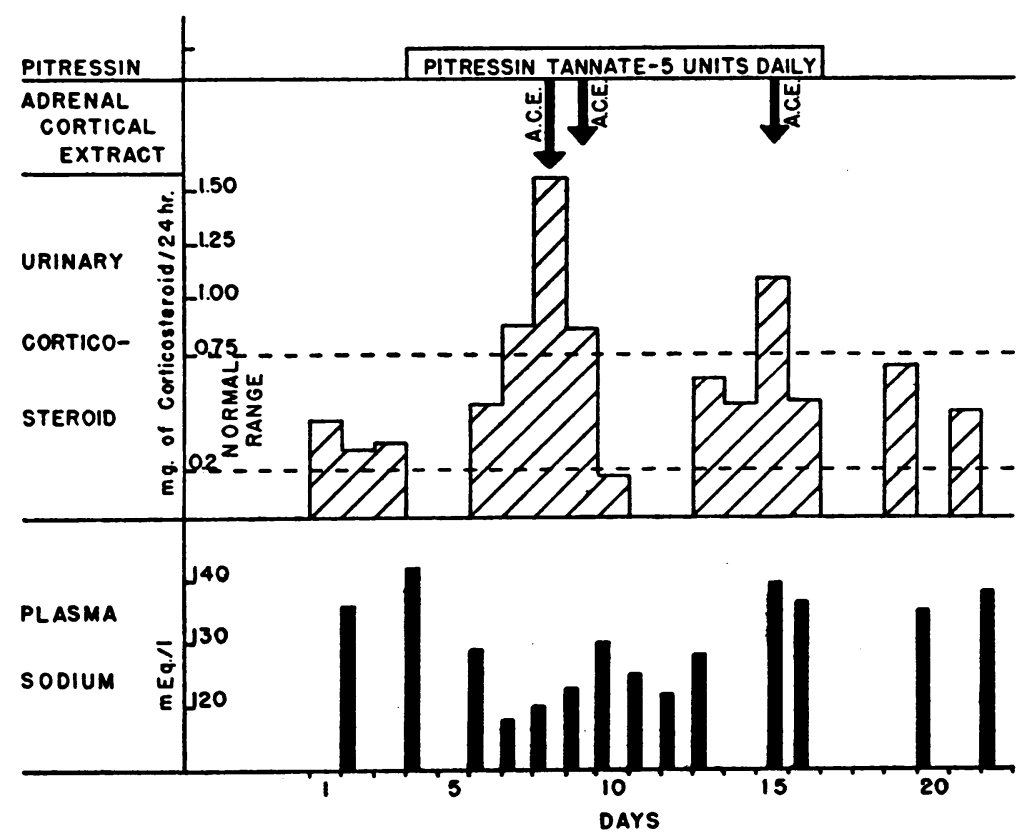

Fig. 3 (Case 11). Alterations in Plasma Sodrum and Urinary Corticosteroid Levels Occurring During Administration of Pitressin Tannate and Adrenal Cortical Extract

dividuals. In the control group, Case 5, who responded after six days of 5 units of pitressin daily with a precipitous drop in the plasma sodium level from 142 to $117 \mathrm{mEq}$. per liter, retained only 2.8 lbs. of fluid. Meanwhile, the patient who gained the most weight in the control group (Case 2), showed only a moderate hyponatremia. Similarly, in the cirrhotic group, Case 10, whose plasma sodium level fell from 133 to $108 \mathrm{mEq}$. per liter, retained only $2 \mathrm{lbs}$. of fluid. This patient, however, lost considerable fluid through vomiting. In most of the patients with cirrhosis an antidiuresis with increasing edema and ascites was associated with a progressive drop in plasma sodium levels.

Case 11 is reported separately for reasons described under Methods. Figures 3 and 4 record the response of this patient following pitressin tannate administration. Within four days, the plasma sodium level fell from 139 to $120 \mathrm{mEq}$. per liter and body weight increased from 109 to 116 lbs.

\section{The Effect of Continued Administration of $\mathrm{Pi}_{i}$ tressin Tannate on Urinary Corticosteroid}

The excretion of corticosteroid has been studied during daily pitressin tannate administration in seven subjects; three with diagnoses of Laennec's cirrhosis, one with chronic alcoholism, and three with no evidence of liver disease. All determinations of corticosteroid excretion in the urine were within the normal range during the control period except in two individuals with cirrhosis whose corticosteroid excretions were $.95 \mathrm{mg}$. per $24 \mathrm{hrs}$. and $.81 \mathrm{mg}$. per $24 \mathrm{hrs}$., respectively.

No appreciable increase in urinary corticosteroid was observed in any subject until a significant decrease in plasma sodium had occurred. During the time that the plasma sodium was maintained at a low level with the continued administration of pitressin tannate, the urinary corticosteroid usually remained above the control levels. Figure 5 illustrates that during the continued administration of pitressin tannate to a normal subject who had little change in plasma sodium, there was no increase in urinary corticosteroids. Figure 6 illustrates that when pitressin tannate produced a striking depression of serum sodium in the cirrhotic, there was a concomitant increase in corticosteroid.

Chromatographic fractionation of corticosteroids excreted by one of these patients, Case 10, has 


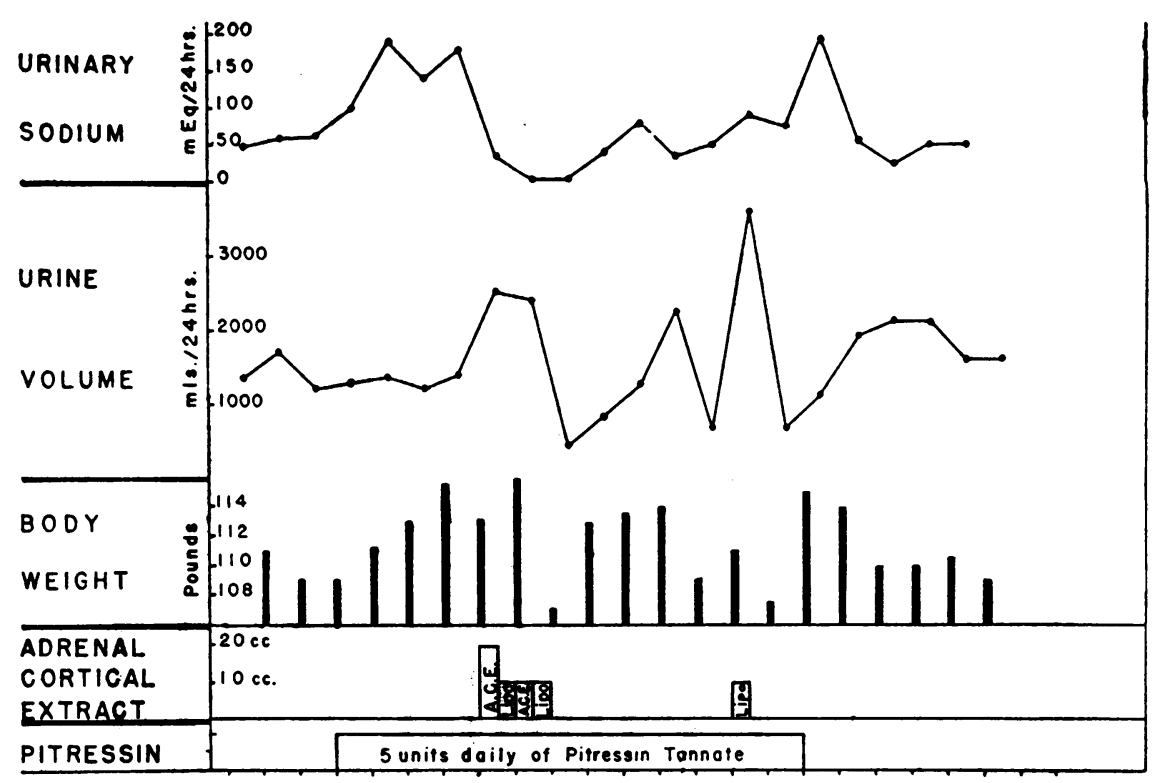

Fig. 4 (Case 11). Alterations in Urinary Sodium Excretion, Urine Volume, and Body Weight Occurring During Administration of Pitressin Tannate and Adrenal Cortical Extract

demonstrated an alpha-ketol which moves more rapidly than desoxycorticosterone, and which forms formaldehyde upon oxidation with periodic acid. Based on the rate of flow, it seems probable that this material contains three oxygens. No further identification has as yet been possible.

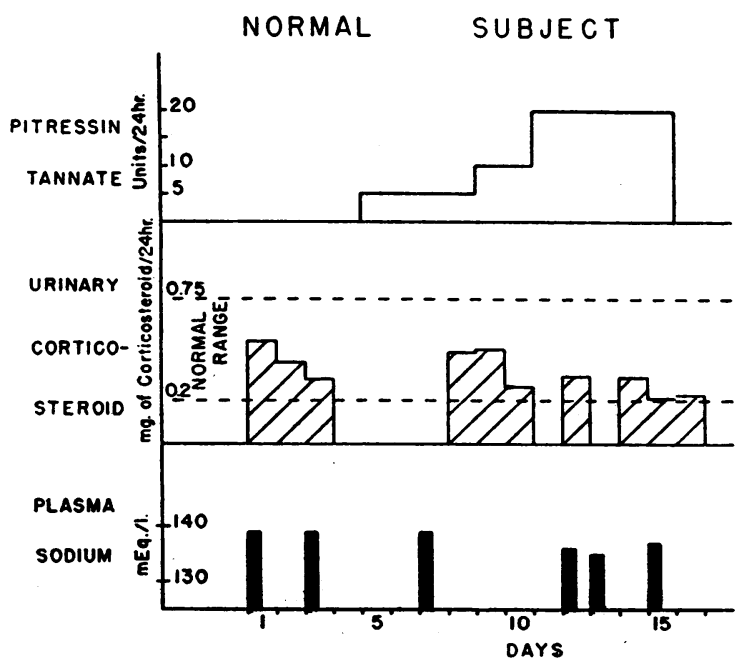

Fig. 5. Effect of Continued Administration of Pitressin Tannate on Plasma Sodium and Urinary Corticostrarom-Normal SUbJect
The Effects of Exogenous Adrenal Steroids on Water and Electrolyte Disturbances Caused by the Continued Administration of Posterior Pituitary Extract

Two patients from the control group, five patients with cirrhosis and Case 11 received adrenal cortical extract during the course of pitressin tannate administration. Adrenal cortical extract appeared to promote salt retention in two controls (Cases 2 and 3 ) when the pitressin dosage was maintained at 5 units per day, but no effect was apparent in Case 3 after pitressin dosage had been increased to 15 units per day.

Adrenal cortical extract was administered for a total of 17 experimental days in the cirrhotic group. It is worth noting that the urine volume and sodium excretion varied considerably from day to day, making it difficult to assess the effects of adrenal cortical extract. Furthermore, when antidiuresis was very pronounced, the urine sodium content was markedly reduced secondary to oliguria (see Case 9). On only two of the 17 experimental days (Day 20, Case 6; Day 17, Case 10) did a sodium retention result which might be ascribed to the effects of adrenal cortical extract. Adrenal cortical extract failed to promote 
an obvious diuresis in either the control or the cirrhotic patients. In Case 7, however, the degree of water retention and weight gain was less after adrenal cortical extract, and in Case 10 a definite weight loss occurred concomitantly.

The hyponatremia resulting from pitressin tannate administration was improved in only one patient (Case 10).

In Case 11, pitressin tannate administration promoted an antidiuresis and natriuresis, both of which were reversed with adrenal cortical extract. Antidiuresis returned as pitressin was continued and was again reversed with adrenal cortical extract, although there was little immediate effect upon sodium excretion. The hyponatremia resulting from pitressin tannate tended to be corrected also.

\section{DISCUSSION}

These experiments have raised the following points for discussion: The tolerance of patients with liver disease to pitressin; the causes of the resulting hyponatremia; the effects of pitressin administration upon adrenal cortical function; and the reversal of the effects of pitressin by adrenal cortical extract.
White, Rubin, and Leiter (9), and Nelson and Welt (10) have found that when relatively small doses of pitressin are given in an acute experiment, no difference in effect is found, and they concluded that the patient with cirrhosis can inactivate physiological doses of pitressin as well as the normal. Our preliminary experiments with small amounts of aqueous pitressin yielded the same result.

It seems probable that extrahepatic sites of pitressin inactivation are capable of removing the antidiuretic activity present in small amounts of pitressin given either intravenously or subcutaneously. Fairly large doses of pitressin are required to demonstrate a defect in hepatic inactivation. Eversole, Birnie, and Gaunt (6) found it necessary to give a dose of 40 milliunits of pitressin to $200 \mathrm{Gm}$. rats in order to demonstrate differences in effectiveness of the intrasplenic or subcutaneous routes. This dose is approximately fifteen times the amount of pitressin required to produce a state of antidiuresis. Heller (11) has found that rabbit blood is capable of inactivating several milliunits of pitressin per cc. of blood and believes that this inactivation actually represents a loose combination with protein. Birnie, Jenkins,

CIRRHOSIS

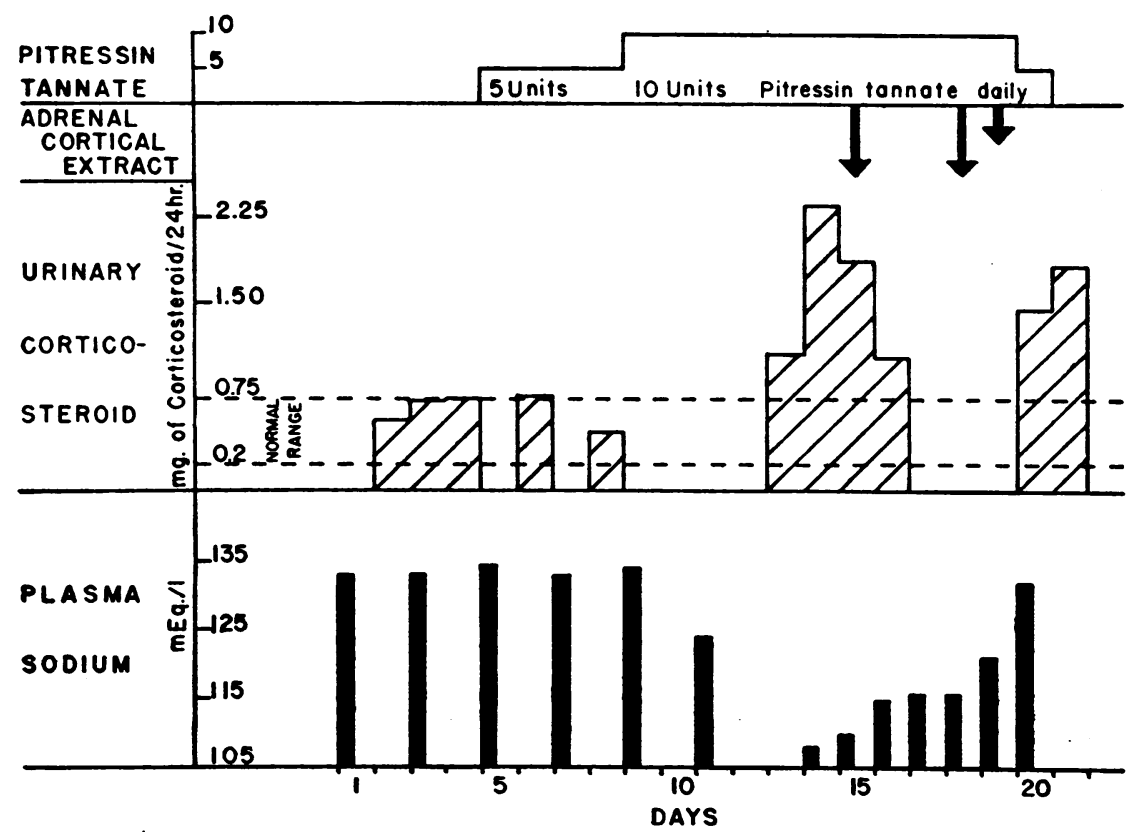

Fig. 6. Effect of Continued Administration of Pitressin Tannate on Plasma Sodium and Urinary Corticosteroid-Patient with Cirrhosis 
Eversole, and Gaunt (12) have found that rat serum is capable of destroying the antidiuretic activity in pitressin and a few preliminary studies in our laboratory indicate that human blood has the same property.

The data of these experiments suggest that by taking advantage of a possible accumulative effect, differences in rate of inactivation of pitressin by patients with and without liver disease can be shown. Although the liver is the most active single tissue in pitressin inactivation, it is only one of many mechanisms which remove antidiuretic activity from blood. Therefore, even if the hepatic inactivating mechanisms are strikingly less efficient than normal, the total overall ability of the body to inactivate pitressin may not be very greatly decreased and the defect is made apparent only when large amounts of pitressin are administered over a period of several days.

Animal experiments by Loewy and Lloyd (13) have compared the effectiveness of pitressin tannate given to normal rats and to rats with fatty livers produced by diet low in protein and high in fat. The fatty livers were capable of inactivating in vitro only one-third of the antidiuretic activity of an amount of pitressin which normal liver could completely destroy. These findings agree with those of Birnie, Blackmore, and Heller (14), who reported that a low protein diet greatly decreases the pitressin inactivating ability of the mouse liver in vitro.

The relatively minor differences in the response between the cirrhotic and the normal group in this study and the complete absence of differences between cirrhotics and normals when pitressin is given intravenously suggest that hepatic inactivation of posterior pituitary hormone probably plays relatively little part in removal of antidiuretic activity from blood under normal physiological conditions and that failure of this process may very well have only minor importance in the production of ascites.

Bartter (15), in discussing an experiment carried out in collaboration with Leaf, has pointed out that the normal individual may be quite sencitive to pitressin tannate with rather strikin $\$$ water retention. Our experiences are certainly in agreement. There is no question that certain normal subjects have considerable antidiuresis as a result of pitressin tannate administration, but the degree of antidiuresis is usually not as marked as in the cirrhotic and frequently, relatively little effect is apparent.

The natriuretic and antidiuretic effects of exogenous pitressin could be minimized presumably by various hormonal and physiologic mechanisms within the body. If this were so, abrupt withdrawal of exogenous pitressin would be expected to lead to sudden and profound diuresis with rapid return of the plasma sodium level to initial levels. This occurred in eight of the ten patients followed. The effects of withdrawal of pitressin were far more obvious than the slow accumulative effects of pitressin administration. The pattern of changes resulting from pitressin administration suggested by these studies are supported, therefore, by the dramatic reversal of effects on discontinuing pitressin tannate.

The effect of prolonged administration of pitressin tannate on the plasma sodium could be mediated in three possible ways. A natriuresis frequently occurred following administration of pitressin tannate in oil. Other investigators, who have studied the excretion of sodium following the administration of aqueous extract of pitressin have been unable to demonstrate a natriuresis in the acute experiment. By the methods used in this study, however, an increased loss of sodium in the urine occurred in four patients, (Cases 5, 6, 7, 10). Equally significant was the acute retention of sodium when pitressin tannate was abruptly withdrawn.

The second way in which the plasma sodium might be depressed is by dilution with retained water. In some patients, this could account for most or all of the decrease in plasma sodium, since as much as ten liters of fluid were retained. It is difficult to account for the decrease in plasma sodium in other patients, however, by either an increased sodium excretion or by simple dilution with retained water. A third mechanism must be considered, that is, a redistribution of sodium from an extracellular to an intracellular position. The suggestion that this may occur has also been made by White, Rubin, and Leiter (9). Pitressin causes a shift of sodium into tissue from plasma in guinea pigs (16). Keutmann (17) has been able to demonstrate an increased intracellular sodium concentration in several patients with edema occurring as a result of heart failure. Whether such 
an intracellular shift of sodium in the series here presented might have occurred in response to pitressin administration, or whether it might have been mediated through an increased amount of circulating adrenal steroids containing three oxygens, is as yet undetermined. The latter possibility must be considered since suggestive evidence has been presented that an increased amount of a three oxygen containing steroid was present in the urine of one patient, and it has been shown that desoxycorticosterone is capable of causing a shift of extracellular sodium into the cell (18). If the alpha-ketol demonstrated in the urine of one patient in this series had physiological activity similar to desoxycorticosterone, it might have been responsible for such a shift. However, the only time that the three oxygen containing steroid was found in these patients was when the plasma sodium level was already at a low level, so that it now seems more likely that the hyponatremia might very well be the stimulus which caused the appearance of the three oxygen containing steroids. A shift of sodium to the intracellular position would seem to be a direct pitressin action since this shift has been reported to occur (9) during the acute administration of small amounts of pitressin.

The lack of direct effect of pitressin tannate administration on adrenal cortical steroid excretion is apparent. Only when the plasma sodium is depressed to a level which is associated with signs of the low salt syndrome could an increased amount of steroid be discovered in the urine. The failure to find an increased amount of steroid does not mean, of course, that the gland itself is not producing more, since it is easily possible that the increased output of the gland might be balanced by increased utilization with the result that no additional hormone was available for wasting in the urine. However, the studies of Nagareda and Gaunt (19) have shown that pitressin in physiological amounts does not cause a change in adrenal ascorbic acid. Studies on the urinary corticosteroid and serum antidiuretic levels during water diuresis have shown that a reciprocity exists and that the antidiuretic activity decreases and the corticosteroid level increases during water diuresis. Since this reciprocity is not a direct one, the hypothesis has been made that a response to a common stimulus (hypotonicity) decreases se- cretion of posterior lobe hormone and increases secretion of adrenal cortical steroids.

The increased level of adrenal cortical steroids in diuresis, and the known opposing effects of adrenal steroids and pitressin, constituted the rationale for administration of adrenal cortical extract concomitantly with pitressin tannate. Only in Case 11 in whom there was some clinical evidence of adrenal insufficiency, did adrenal cortical extract produce an obvious diuresis with retention of sodium. In several of the remaining cases, an apparent retention of sodium occurred on some occasions, but without obvious diuresis. The failure to produce this effect more frequently may be the result of an inadequate dosage. No attempts to reproduce these experiments using cortisone or 17-hydroxycortisone have been made.

\section{SUM MARY}

1. Pitressin tannate in oil was given by intramuscular injection daily to five patients with cirrhosis of the liver and to five "control" patients. One patient, a chronic alcoholic with evidence of poor adrenal function, was also studied.

2. Administration of pitressin tannate in oil can produce hyponatremia and antidiuresis in both the control and the cirrhotic patients. These effects are greater in the cirrhotic, and frequently lead to a stage of progressive hyponatremia and edema.

3. The opposite effect, profound diuresis and return of plasma sodium towards normal, occurs promptly when exogenous pitressin is withdrawn.

4. Pitressin administration lowers plasma sodium levels by at least two mechanisms: Antidiuresis with dilution of extracellular sodium by retained water; and a direct natriuresis. A third mechanism must be considered: A shift of sodium from the extracellular to the intracellular space.

5. Urinary excretion of corticosteroid increases when plasma sodium concentration falls to low levels, but does not increase as a result of pitressin administration per se.

6. Adrenal cortical extract produced an obvious diuresis and retention of sodium in only one patient who had developed water retention and hyponatremia as a result of pitressin tannate administration. In several other patients an apparent retention of sodium occurred on occasion without obvious diuresis. 
APPENDIX

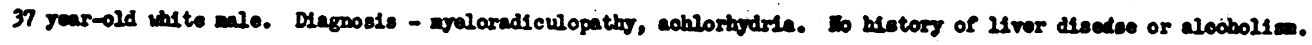

\begin{tabular}{|c|c|c|c|c|c|c|c|c|c|c|c|}
\hline Day & $\begin{array}{l}\text { P1t- } \\
\text { reasin } \\
\text { tannato } \\
\text { unfto/day }\end{array}$ & $\begin{array}{l}\text { Ldrenel } \\
\text { Cortical } \\
\text { prtract } \\
\text { cod } / 4 \mathrm{hrs} \text {. }\end{array}$ & $\begin{array}{l}\text { Hetght } \\
\text { Ibe. }\end{array}$ & $\begin{array}{l}\text { Vorino } \\
\text { Vol. } \\
\text { ec./24 hrs. }\end{array}$ & $\begin{array}{c}0.100 \\
\text { Nae } \\
\text { meq. } / 24 \text { hrs. }\end{array}$ & 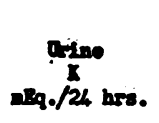 & 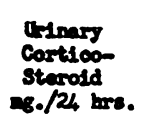 & 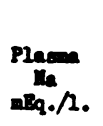 & 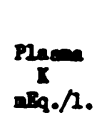 & $\begin{array}{l}\text { Sodive } \\
\text { Intake } \\
\text { nisq. } / 24 \mathrm{hrse} \text {. }\end{array}$ & Remarks \\
\hline $\begin{array}{l}1 \\
2 \\
3\end{array}$ & & & $\begin{array}{l}139 \\
139 \\
139\end{array}$ & $\begin{array}{l}1680 \\
1260 \\
1750\end{array}$ & $\begin{array}{r}168 \\
86 \\
70\end{array}$ & $\begin{array}{l}67 \\
53 \\
66 \\
\end{array}$ & $\begin{array}{l}0.54 \\
0.42 \\
0.32 \\
\end{array}$ & $\begin{array}{l}139 \\
139 \\
\end{array}$ & $\begin{array}{l}4.3 \\
4.2 \\
\end{array}$ & 216 & \multirow{2}{*}{$\begin{array}{l}\text { Shoved no } \\
\text { ovldenco } \\
\text { of edean } \\
\text { at any } \\
\text { tise. }\end{array}$} \\
\hline $\begin{array}{r}4 \\
5 \\
6 \\
7 \\
8 \\
9 \\
10 \\
11 \\
12 \\
13 \\
24\end{array}$ & $\begin{array}{c}5 u \\
5 u \\
5 u \\
5 u \\
20 u \\
10 u \\
20 u \\
20 u \\
20 u \\
20 u \\
20 u\end{array}$ & & $\begin{array}{l}139 \\
139.5 \\
139 \\
139 \\
140.5 \\
139 \\
139 \\
138 \\
138 \\
138 \\
140\end{array}$ & $\begin{array}{r}1060 \\
1255 \\
1525 \\
1285 \\
2050 \\
1520 \\
1495 \\
1000 \\
2070 \\
1000 \\
885\end{array}$ & $\begin{array}{r}94 \\
113 \\
130 \\
100 \\
142 \\
103 \\
81 \\
139 \\
164 \\
108 \\
130\end{array}$ & $\begin{array}{r}60 \\
72 \\
126 \\
48 \\
84 \\
60 \\
69 \\
75 \\
76 \\
81 \\
61\end{array}$ & $\begin{array}{l}0.47 \\
0.50 \\
0.30 \\
0.36 \\
0.35 \\
0.22\end{array}$ & $\begin{array}{l}136 \\
135 \\
137\end{array}$ & $\begin{array}{l}4.7 \\
3.8\end{array}$ & & \\
\hline $\begin{array}{l}15 \\
16 \\
27\end{array}$ & & & $\begin{array}{l}244 \\
213 \\
236.5\end{array}$ & $\begin{array}{l}1225 \\
5200\end{array}$ & $\frac{144}{80}$ & 255 & 0.25 & & & & \\
\hline
\end{tabular}

Case I-M. C.

35 year-ald thite male. Diagnosis - migrating thrombophlebitis. Denles alcoholism or history of liver discase. Liver not pelpable. Liver function tests normel.

\begin{tabular}{|c|c|c|c|c|c|c|c|c|c|c|c|}
\hline Day & $\begin{array}{l}\text { P1t- } \\
\text { ressin } \\
\text { tannate } \\
\text { unts/day }\end{array}$ & $\begin{array}{l}\text { Adrobal } \\
\text { Cort1cal } \\
\text { Extract } \\
\text { ce. } / 24 \text { brs. }\end{array}$ & $\begin{array}{l}\text { Welght } \\
\text { Ibs. }\end{array}$ & $\begin{array}{c}\text { Urine } \\
\text { Vol. } \\
\text { ce./24 brs. }\end{array}$ & $\begin{array}{l}\mathrm{Urlne}_{\mathrm{Na}} \\
\mathrm{Na} \\
\mathrm{mpq} / 24 \mathrm{hrs} .\end{array}$ & $\begin{array}{l}\text { Orine } \\
\mathbb{S} \\
\text { maq./24 hrs. }\end{array}$ & $\begin{array}{l}\text { Urinary } \\
\text { Cortico- } \\
\text { Steroid } \\
\text { mg./2/ hrs. }\end{array}$ & $\begin{array}{c}\text { Plasma } \\
\text { Ne } \\
\text { maq. } / 1 .\end{array}$ & $\begin{array}{c}\text { Plasina } \\
\mathrm{x} \\
\mathrm{mE}_{\mathrm{q}} \cdot / 1\end{array}$ & $\begin{array}{l}\text { Sodiun } \\
\text { Intake } \\
\text { meq./24 }\end{array}$ & $\begin{array}{l}\text { Reanarks } \\
\text { hra. }\end{array}$ \\
\hline $\begin{array}{l}2 \\
2 \\
3\end{array}$ & & & $\begin{array}{l}153.8 \\
155 \\
154.3\end{array}$ & $\begin{array}{l}2200 \\
1195 \\
2295\end{array}$ & $\begin{array}{r}132 \\
95 \\
124\end{array}$ & $\begin{array}{l}43 \\
42 \\
40\end{array}$ & $\begin{array}{l}0.54 \\
0.36\end{array}$ & $\begin{array}{l}143 \\
142\end{array}$ & $\begin{array}{l}5.1 \\
4.3\end{array}$ & & $\begin{array}{l}\text { Actual salt } \\
\text { inteake } \\
\text { unknown. }\end{array}$ \\
\hline $\begin{array}{r}4 \\
5 \\
6 \\
7 \\
8 \\
9 \\
10 \\
11 \\
12 \\
13\end{array}$ & $\begin{array}{l}5 u \\
5 u \\
5 u \\
5 u \\
5 u \\
5 u \\
5 u \\
5 u \\
5 u \\
5 u\end{array}$ & $102 *-10 A$ & $\begin{array}{l}154 \\
157.8 \\
157.5 \\
156.5 \\
161 \\
160 \\
160.8 \\
160.5 \\
162.8 \\
161.3\end{array}$ & $\begin{array}{r}780 \\
2720 \\
790 \\
960 \\
2270 \\
1560 \\
1920 \\
1605 \\
2100 \\
2580\end{array}$ & $\begin{array}{r}102 \\
98 \\
42 \\
136 \\
119 \\
123 \\
102 \\
149 \\
85 \\
193\end{array}$ & $\begin{array}{l}57 \\
59 \\
45 \\
56 \\
56 \\
53 \\
50 \\
72 \\
32 \\
56\end{array}$ & $\begin{array}{l}0.73 \\
0.59 \\
0.70\end{array}$ & $\begin{array}{l}u_{43} \\
138 \\
143 \\
133 \\
\\
135 \\
130\end{array}$ & $\begin{array}{l}3.7 \\
3.7 \\
4.4 \\
5.2 \\
4.7 \\
4.5\end{array}$ & 90 & $\begin{array}{l}\text { No } \\
\text { apparent } \\
\text { edean at } \\
\text { and time. }\end{array}$ \\
\hline$\frac{14}{15}$ & & & $\begin{array}{l}161 \\
155.5\end{array}$ & 3790 & 13 & 52 & & 142 & 4.2 & & \\
\hline
\end{tabular}

- L L Lipo-adrenal cortex

$A=$ Aqueous adrenal cortex

Case II-J. W. 


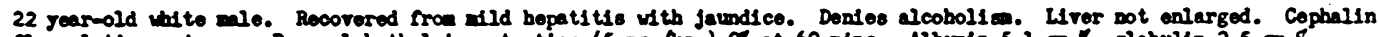

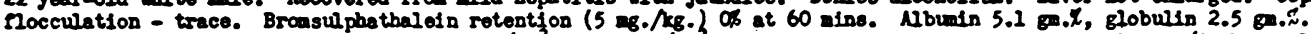

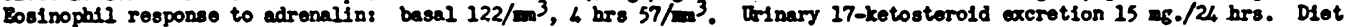
high in potassive due to protinal and fresh frut suppleant.

\begin{tabular}{|c|c|c|c|c|c|c|c|c|c|c|}
\hline Day & $\begin{array}{l}\text { PIt- } \\
\text { ressin } \\
\text { tamnato } \\
\text { units/day }\end{array}$ & $\begin{array}{l}\text { Adrenal } \\
\text { Cortifcel } \\
\text { Bxtract } \\
\text { cc./24 hrs. }\end{array}$ & $\begin{array}{l}\text { Welght } \\
\text { Ibs. }\end{array}$ & $\begin{array}{c}\text { Orine } \\
\text { Vol. } \\
\text { cc./24 brs. }\end{array}$ & 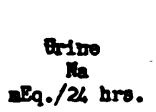 & 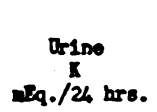 & $\begin{array}{l}\text { Colnary } \\
\text { Cortico- } \\
\text { storoid } \\
\text { ig./24 hrs. }\end{array}$ & 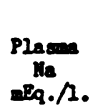 & 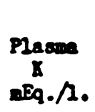 & $\begin{array}{l}\text { Sodive } \\
\text { Intake } \\
\text { ag. } / 26 \text { hre. }\end{array}$ \\
\hline $\begin{array}{l}1 \\
2 \\
3 \\
4\end{array}$ & & & $\begin{array}{l}164.5 \\
165 \\
164 \\
164\end{array}$ & $\begin{array}{l}2500 \\
1920 \\
1300 \\
1540\end{array}$ & $\begin{array}{r}219 \\
119 \\
33 \\
22\end{array}$ & $\begin{array}{r}118 \\
93 \\
100 \\
121\end{array}$ & & & & $\begin{array}{l}\text { No edema } \\
\text { or } \\
\text { ascites }\end{array}$ \\
\hline $\begin{array}{c}5 \\
6 \\
7 \\
8 \\
9 \\
10 \\
11 \\
12 \\
13 \\
14 \\
15 \\
16 \\
17 \\
18 \\
19 \\
20\end{array}$ & $\begin{array}{c}5 u \\
5 u \\
5 u \\
5 u \\
5 u \\
5 u \\
5 u \\
5 v \\
5 u \\
10 u \\
10 u \\
10 u \\
15 u \\
15 u \\
15 u \\
15 u\end{array}$ & $\begin{array}{l}10 L-20 A= \\
18 L-23 A \\
10 L-20 A \\
15 L=20 A\end{array}$ & $\begin{array}{l}164 \\
166.3 \\
166.3 \\
167 \\
167 \\
167 \\
167 \\
168 \\
166 \\
169.5 \\
171.5 \\
170 \\
170 \\
174.3 \\
177 \\
181 \\
\end{array}$ & $\begin{array}{r}1200 \\
2060 \\
2320 \\
960 \\
1920 \\
2680 \\
1320 \\
1380 \\
2080 \\
1380 \\
2320 \\
1380 \\
1160 \\
1460 \\
1100 \\
1140 \\
\end{array}$ & $\begin{array}{r}46 \\
180 \\
122 \\
60 \\
65 \\
60 \\
27 \\
59 \\
92 \\
152 \\
58 \\
66 \\
64 \\
166 \\
211 \\
90\end{array}$ & $\begin{array}{r}113 \\
113 \\
102 \\
73 \\
120 \\
144 \\
103 \\
105 \\
112 \\
135 \\
157 \\
130 \\
159 \\
108 \\
119 \\
84\end{array}$ & & $\begin{array}{l}140 \\
137 \\
110 \\
136 \\
135 \\
135 \\
133 \\
129 \\
127 \\
125\end{array}$ & $\begin{array}{l}4.4 \\
4.5 \\
4.7 \\
4.4 \\
4.0 \\
4.0 \\
3.8 \\
4.1 \\
4.2 \\
4.1\end{array}$ & \\
\hline $\begin{array}{l}21 \\
22 \\
23 \\
24 \\
25\end{array}$ & & $L=L i p o-$ & $\begin{array}{l}178 \\
175.5 \\
166 \\
167.8 \\
\text { renal ce }\end{array}$ & $\begin{array}{l}2190 \\
6840 \\
1880\end{array}$ & $\begin{array}{r}259 \\
68 \\
6\end{array}$ & $\begin{array}{r}217 \\
68 \\
85\end{array}$ & & $\begin{array}{l}128 \\
138 \\
145\end{array}$ & $\begin{array}{l}4.3 \\
3.9 \\
3.4\end{array}$ & \\
\hline
\end{tabular}

CASE III-S. S.

33 jear-ald Negro male. Recovered from lobar pnevania. Dendes alcohollan. Ho ovidence of I1ver disease. Bouse diet. Fluids ad lib. Urine not collected.

\begin{tabular}{|c|c|c|c|c|c|c|c|c|c|c|c|}
\hline Day & $\begin{array}{l}\text { P1t- } \\
\text { ressin } \\
\text { tannate } \\
\text { unito/dar }\end{array}$ & $\begin{array}{l}\text { Adronal } \\
\text { Cortical } \\
\text { Bxtract } \\
\text { ce./24 hrs. }\end{array}$ & $\begin{array}{l}\text { Weight } \\
\text { Ibs. }\end{array}$ & $\begin{array}{c}\text { Orine } \\
\text { Vol. } \\
\text { ce. } / 24 \text { hrs. }\end{array}$ & $\begin{array}{c}\text { Ordine } \\
\text { Ila } \\
\text { mEg. } / 2 / 4 \mathrm{hrs} .\end{array}$ & $\begin{array}{c}\text { Orine } \\
\mathrm{k} \\
\text { neh. } / 2 \mathrm{~h} \mathrm{hrs} .\end{array}$ & $\begin{array}{l}\text { Uelnary } \\
\text { Cortico- } \\
\text { Sterold } \\
\text { ag. } / 24 \mathrm{hrs} \text {. }\end{array}$ & $\begin{array}{c}\text { Plasma } \\
\text { Na } \\
\text { Eq. } / 1 .\end{array}$ & $\begin{array}{c}\text { Plasma } \\
\mathbf{K} \\
\mathrm{Eq} \cdot / 1\end{array}$ & $\begin{array}{l}\text { Sodium } \\
\text { Intake } \\
\text { m5q. } 24\end{array}$ & $\begin{array}{l}\text { Resarks } \\
\text { hrs. }\end{array}$ \\
\hline 1 & & & 150 & & & & & 162 & 5.2 & $\begin{array}{l}\text { Approx. } \\
190\end{array}$ & \multirow{2}{*}{$\begin{array}{l}\text { No edeana } \\
\text { at any } \\
\text { time } \\
\text { during } \\
\text { study. }\end{array}$} \\
\hline $\begin{array}{l}2 \\
3 \\
4 \\
5 \\
6 \\
7 \\
8\end{array}$ & $\begin{array}{l}5 u \\
5 u \\
5 u \\
5 u \\
5 u \\
5 u \\
5 u\end{array}$ & & $\begin{array}{l}150 \\
150 \\
150 \\
152 \\
152 \\
153.5 \\
152.5\end{array}$ & & & & & $\begin{array}{l}142 \\
145 \\
139 \\
136 \\
134 \\
133 \\
138\end{array}$ & $\begin{array}{l}5.1 \\
5.0 \\
4.5 \\
5.3 \\
4.5 \\
4.4\end{array}$ & & \\
\hline $\begin{array}{r}9 \\
10 \\
11\end{array}$ & & & $\begin{array}{l}152 \\
151.5 \\
152\end{array}$ & & & & & $\begin{array}{l}140 \\
142\end{array}$ & $\begin{array}{l}3.8 \\
4.3\end{array}$ & & \\
\hline
\end{tabular}

Case IV-J. S. 


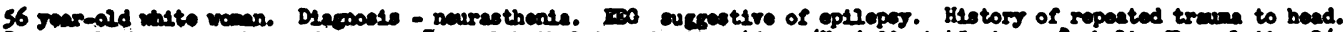

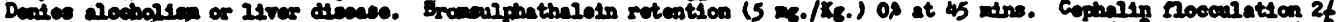

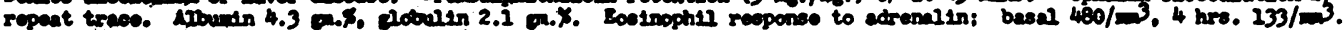
Orinary 17-kotootarold exeretion 3.8 \%./24 tres.

\begin{tabular}{|c|c|c|c|c|c|c|c|c|c|c|}
\hline Dor & 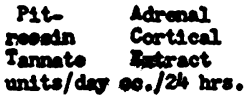 & $\begin{array}{l}\text { Wolcht } \\
\text { 2be. }\end{array}$ & $\begin{array}{l}\text { Orine } \\
\text { Dol. } \\
. / 24 \text { ires. }\end{array}$ & $\begin{array}{l}\text { Dring } \\
\text { Ite } \\
=2 . / 24 \text { hre. }\end{array}$ & $\begin{array}{l}\text { Urino } \\
x \\
=9 . / 24 \text { hrs. }\end{array}$ & $\begin{array}{l}\text { Urinary } \\
\text { Corticeo } \\
\text { Steroidd } \\
\text { ng. } 124 \text { hrs. }\end{array}$ & 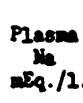 & $\begin{array}{c}\text { Plasme } \\
x \\
=0 . / 2 .\end{array}$ & $\begin{array}{l}\text { Sodsum } \\
\text { Intake } \\
\text { neq. } 12\end{array}$ & $\begin{array}{l}\text { Kemarks } \\
\text { hro. }\end{array}$ \\
\hline $\begin{array}{l}2 \\
2 \\
3\end{array}$ & & $\begin{array}{l}129 \\
129.8 \\
229.8\end{array}$ & $\begin{array}{l}1732 \\
2130 \\
2558\end{array}$ & $\begin{array}{l}125 \\
167 \\
123\end{array}$ & $\begin{array}{l}61 \\
74 \\
82\end{array}$ & $\begin{array}{l}0.42 \\
0.52\end{array}$ & $\begin{array}{l}140 \\
142\end{array}$ & $\begin{array}{l}4.6 \\
4.3\end{array}$ & 216 & $\begin{array}{l}\text { No odema, ascites } \\
\text { Abd. circ. } 34 \frac{1}{2} \text {. }\end{array}$ \\
\hline $\begin{array}{l}4 \\
5 \\
6 \\
7 \\
8 \\
9\end{array}$ & $\begin{array}{l}5 u \\
5 \\
5 \\
5 \\
5 \\
5 \\
5 \\
5 \\
u\end{array}$ & $\begin{array}{l}130 \\
133.5 \\
135.3 \\
132 \\
131 \\
133.5\end{array}$ & $\begin{array}{l}1440 \\
1700 \\
1535 \\
1070 \\
1355 \\
2350\end{array}$ & $\begin{array}{r}147 \\
282 \\
242 \\
48 \\
94 \\
265\end{array}$ & $\begin{array}{l}94 \\
75 \\
74 \\
48 \\
56 \\
66\end{array}$ & $\begin{array}{l}0.78 \\
0.58\end{array}$ & $\begin{array}{l}136 \\
122 \\
120 \\
118\end{array}$ & $\begin{array}{l}4.9 \\
4.0 \\
4.5 \\
5.7\end{array}$ & $\cdot$ & $\begin{array}{l}\text { Vomited } 1200 \mathrm{cc} \text {. } \\
\text { Abd. circ. } 37^{n} \text {. ankl. } \\
\text { odema } 14 .\end{array}$ \\
\hline 20 & & 132.8 & 2122 & 75 & 43 & & 117 & 5.4 & & $\begin{array}{l}\text { Abd. ctrc. 38n, ankle } \\
\text { edema cleared }\end{array}$ \\
\hline $\begin{array}{l}21 \\
12 \\
13\end{array}$ & & $\begin{array}{l}127 \\
123.8 \\
126\end{array}$ & $\begin{array}{l}3810 \\
1805\end{array}$ & $\begin{array}{l}5.6 \\
7.6\end{array}$ & $\begin{array}{l}32 \\
55\end{array}$ & & $\begin{array}{l}120 \\
133 \\
135 \\
\end{array}$ & $\begin{array}{l}5.4 \\
5.4 \\
3.9 \\
\end{array}$ & & Abd. ctrc. $34 "$ \\
\hline
\end{tabular}

CASE V-G. H.

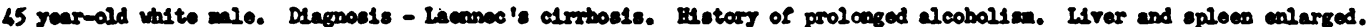

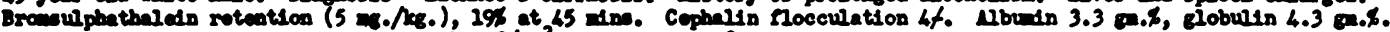

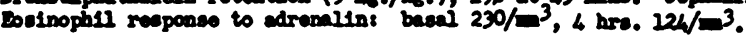

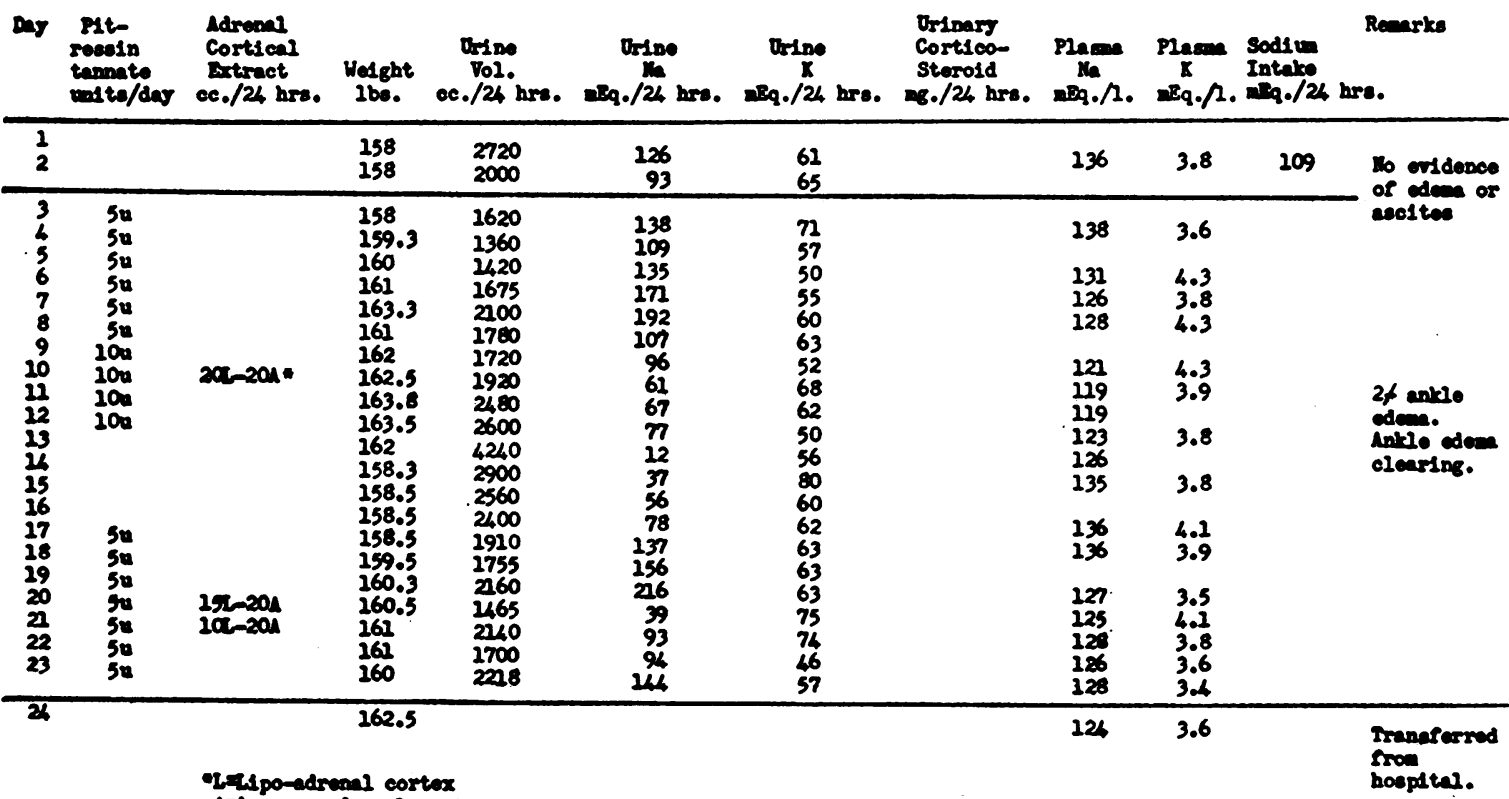




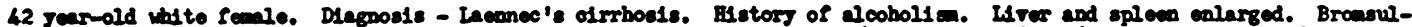

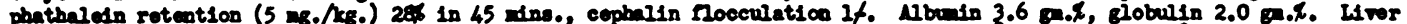

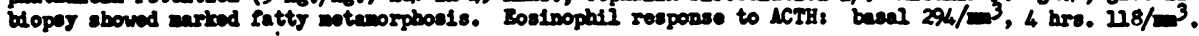

\begin{tabular}{|c|c|c|c|c|c|c|c|c|c|c|c|}
\hline Day & $\begin{array}{l}\text { P1t } \\
\text { resedin } \\
\text { tennatid } \\
\text { velte/dn }\end{array}$ & $\begin{array}{l}\text { Adrepal } \\
\text { Cortical } \\
\text { atract } \\
\text { ce./24 hre. }\end{array}$ & $\begin{array}{l}\text { Wedght } \\
\text { Ibe. }\end{array}$ & $\begin{array}{c}\text { Unine } \\
\text { Vol. } \\
\text { c./24 hro. }\end{array}$ & 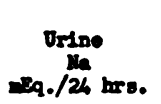 & $\begin{array}{c}\text { Dofno } \\
\mathrm{X} \\
=39 . / 24 \mathrm{hrs} .\end{array}$ & $\begin{array}{l}\text { Orinary } \\
\text { Cortico } \\
\text { storold } \\
\text { g./2h hrs. }\end{array}$ & $\underset{\text { Plage }}{\text { Pla. }}$ & $\begin{array}{l}\text { Plaga } \\
\mathbf{x} \\
\mathrm{Bq} \cdot \mathbf{1} .\end{array}$ & 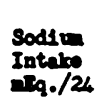 & $\begin{array}{l}\text { Renarks } \\
\text { hre. }\end{array}$ \\
\hline $\begin{array}{l}1 \\
2 \\
3 \\
4\end{array}$ & & & $\begin{array}{l}176 \\
176 \\
175.3 \\
175.5\end{array}$ & $\begin{array}{l}2440 \\
1545 \\
1860 \\
2140\end{array}$ & $\begin{array}{l}51 \\
72 \\
65 \\
65\end{array}$ & $\begin{array}{l}47 \\
26 \\
23 \\
37\end{array}$ & $\begin{array}{l}0.81 \\
0.80\end{array}$ & & & 116 & $\begin{array}{l}\text { Ho ankle } \\
\text { edeas or } \\
\text { ascltes. } \\
\text { Abd. circ. } \\
\text { 43t:. }\end{array}$ \\
\hline
\end{tabular}

\begin{tabular}{|c|c|c|c|c|c|c|c|c|c|c|}
\hline $\begin{array}{r}5 \\
6 \\
7 \\
8 \\
9 \\
10 \\
11 \\
12 \\
13\end{array}$ & $\begin{array}{l}5 u \\
5 u \\
5 u \\
5 u \\
5 u \\
5 u \\
5 u \\
5 u \\
5 u\end{array}$ & $\begin{array}{l}20 \mathrm{~L}-20 \mathrm{~A} \\
20 \mathrm{~L}-20 \mathrm{~A}\end{array}$ & $\begin{array}{l}176.5 \\
180 \\
184 \\
187.5 \\
189 \\
188.5 \\
190.8 \\
191.5 \\
191.3\end{array}$ & $\begin{array}{l}465 \\
547 \\
600 \\
465 \\
1170 \\
1040 \\
1615 \\
1805 \\
1075\end{array}$ & $\begin{array}{r}92 \\
93 \\
213 \\
95 \\
175 \\
92 \\
167 \\
260 \\
95\end{array}$ & $\begin{array}{l}43 \\
30 \\
40 \\
25 \\
77 \\
55 \\
40 \\
45 \\
39\end{array}$ & $\begin{array}{l}0.38 \\
0.55 \\
1.02 \\
0.97 \\
0.68\end{array}$ & $\begin{array}{l}139 \\
129 \\
221 \\
126 \\
113 \\
113 \\
113 \\
112\end{array}$ & $\begin{array}{l}4.2 \\
3.8 \\
4.1 \\
4.3 \\
4.1 \\
4.2 \\
4.7\end{array}$ & 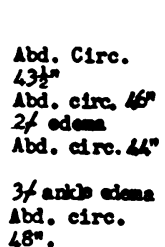 \\
\hline
\end{tabular}

\begin{tabular}{|c|c|c|c|c|c|c|c|c|}
\hline $\begin{array}{l}\mathbf{1 4} \\
\mathbf{1 5}\end{array}$ & $\begin{array}{l}193.5 \\
282.3 \\
271.3\end{array}$ & $\begin{array}{l}5425 \\
4690\end{array}$ & $\begin{array}{l}83 \\
76\end{array}$ & $\begin{array}{l}54 \\
52\end{array}$ & 1.30 & $\begin{array}{l}120 \\
129\end{array}$ & $\begin{array}{l}5.2 \\
4.6\end{array}$ & $\begin{array}{l}\text { Pace purts } \\
\text { Bdoneleared } \\
\text { Abd. cire. } \\
42^{\circ}\end{array}$ \\
\hline
\end{tabular}

CASE VII-N. K.

39 year old white fewele. Diagnosis - Leennec's cirrhosis. History of chrontc alcobollsa. Liver onlarged, tender. Two previous paracenteses. Bromsulphathalein rotention $(5 \mathrm{mg} . / \mathrm{kg})$ 145 at 45 alns. Cophalin 1 Iocculation 24. Albumin

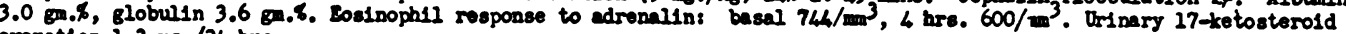
exorotion $1.3 \mathrm{mg} . / 21 \mathrm{hre}$.

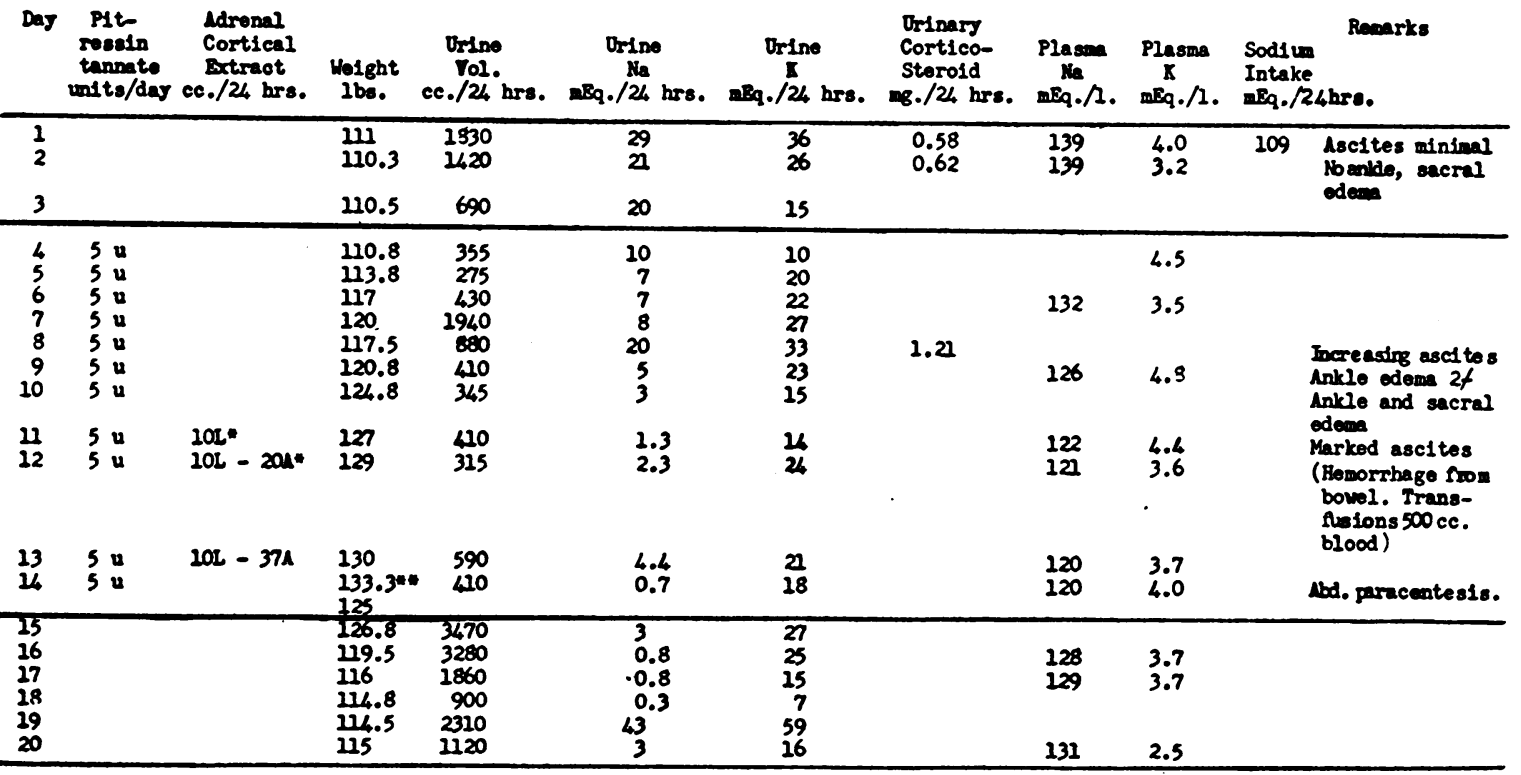




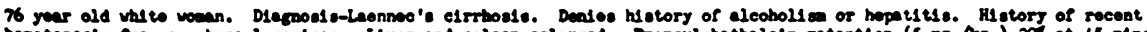
(5 m.

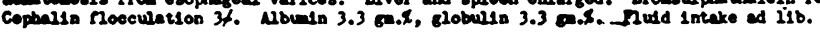

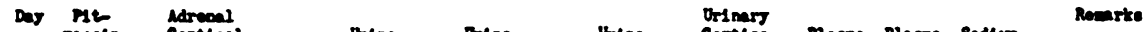

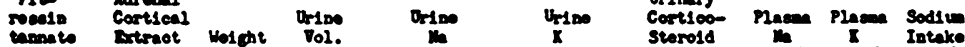

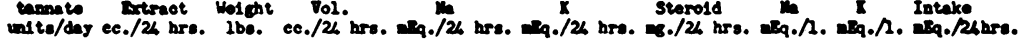

\begin{tabular}{|c|c|c|c|c|c|c|c|c|c|c|}
\hline $\begin{array}{l}2 \\
2 \\
3 \\
4 \\
5\end{array}$ & & & $\begin{array}{l}124.8 \\
123.5\end{array}$ & $\begin{array}{l}1220 \\
1235 \\
2240 \\
2285 \\
1918\end{array}$ & $\begin{array}{l}23 \\
27 \\
35 \\
53 \\
62\end{array}$ & $\begin{array}{l}37 \\
51 \\
31 \\
63 \\
42\end{array}$ & $\begin{array}{l}233 \\
232\end{array}$ & $\begin{array}{l}4.6 \\
6.3\end{array}$ & 61 & to erldesce of ederen \\
\hline $\begin{array}{r}6 \\
7 \\
8 \\
9 \\
20 \\
21 \\
12 \\
13 \\
24 \\
25 \\
16 \\
17 \\
18 \\
19 \\
20\end{array}$ & $\begin{array}{l}5 \mathrm{~b} \\
5 \mathrm{u} \\
5 \mathrm{u} \\
5 \mathrm{u} \\
5 \mathrm{u} \\
5 \mathrm{u} \\
10 \mathrm{u} \\
20 \mathrm{u} \\
10 \mathrm{u} \\
20 \mathrm{u}\end{array}$ & $\begin{array}{l}25 L-2010 \\
2 \pi-201\end{array}$ & $\begin{array}{l}123 \\
121 \\
126 \\
128.5 \\
129 \\
128 \\
126 \\
128 \\
131.5 \\
132.8 \\
136.5 \\
126.3 \\
126.5 \\
122 \\
125.5 \\
\end{array}$ & $\begin{array}{r}300 \\
1430 \\
390 \\
370 \\
2000 \\
2635 \\
2420 \\
815 \\
245 \\
495 \\
4520 \\
1520 \\
2825 \\
2860 \\
2440\end{array}$ & $\begin{array}{r}24 \\
232 \\
6 \\
49 \\
91 \\
35 \\
37 \\
76 \\
256 \\
28 \\
121 \\
80 \\
215 \\
170 \\
162 \\
\end{array}$ & $\begin{array}{l}17 \\
64 \\
20 \\
70 \\
56 \\
43 \\
59 \\
39 \\
65 \\
21 \\
52 \\
21 \\
35 \\
37 \\
55\end{array}$ & $\begin{array}{l}118 \\
111 \\
112 \\
117 \\
132 \\
133\end{array}$ & $\begin{array}{l}4.3 \\
4.2 \\
4.0 \\
3.9 \\
3.6 \\
4.4\end{array}$ & $\begin{array}{l}208 \\
168 \\
199 \\
156 \\
156 \\
190 \\
156\end{array}$ & 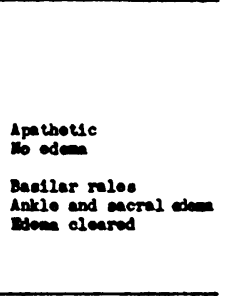 \\
\hline $\begin{array}{l}21 \\
22 \\
23 \\
26\end{array}$ & $\begin{array}{l}10 \mathrm{u} \\
10 \mathrm{u} \\
10 \mathrm{u} \\
20 \mathrm{u}\end{array}$ & & $\begin{array}{l}124.8 \\
124.8 \\
224 \\
226.3\end{array}$ & $\begin{array}{r}2255 \\
1860 \\
780 \\
2545\end{array}$ & $\begin{array}{r}159 \\
110 \\
81 \\
271\end{array}$ & $\begin{array}{l}53 \\
51 \\
44 \\
53\end{array}$ & $\begin{array}{l}134 \\
130 \\
119\end{array}$ & $\begin{array}{l}4.0 \\
4.0 \\
4.2\end{array}$ & & \\
\hline $\begin{array}{l}25 \\
26 \\
21 \\
20 \\
29 \\
30 \\
31 \\
32 \\
33 \\
34\end{array}$ & & & $\begin{array}{l}125.8 \\
122.5 \\
122 \\
123 \\
123 \\
122 \\
123.5 \\
123 \\
123 \\
123\end{array}$ & $\begin{array}{l}4536 \\
2165 \\
1790 \\
1600 \\
2110 \\
2570 \\
2940 \\
2305 \\
2590 \\
2000\end{array}$ & $\begin{array}{c}16 \\
39 \\
82 \\
78 \\
18 \\
132 \\
95 \\
218 \\
259 \\
109\end{array}$ & $\begin{array}{l}38 \\
46 \\
52 \\
28 \\
60 \\
58 \\
50 \\
60 \\
60 \\
65\end{array}$ & $\begin{array}{r}136 \\
238 \\
\end{array}$ & $\begin{array}{l}4.5 \\
4.6 \\
\end{array}$ & & \\
\hline $\begin{array}{l}35 \\
36 \\
37 \\
38 \\
39 \\
40 \\
42 \\
42 \\
43\end{array}$ & $\begin{array}{l}20 u \\
10 z \\
20 u \\
10 u \\
10 u \\
10 u \\
10 u \\
10 u \\
10 u \\
10 v\end{array}$ & $\begin{array}{l}2 \alpha= \\
2 \alpha \\
2 \alpha-304 \\
2 \alpha-30\end{array}$ & $\begin{array}{l}123 \\
123 \\
125.3 \\
128.5 \\
130.3 \\
128 \\
128.5 \\
128.3 \\
123.5\end{array}$ & $\begin{array}{r}2410 \\
1650 \\
950 \\
1340 \\
1050 \\
480 \\
1310 \\
3060 \\
1100 \\
\\
1215\end{array}$ & $\begin{array}{r}152 \\
209 \\
112 \\
190 \\
73 \\
22 \\
126 \\
67 \\
49 \\
\\
11\end{array}$ & $\begin{array}{l}20 \\
36 \\
40 \\
45 \\
41 \\
19 \\
38 \\
18 \\
23 \\
\\
21\end{array}$ & $\begin{array}{l}116 \\
118 \\
119 \\
113 \\
118 \\
129\end{array}$ & $\begin{array}{l}6.0 \\
4.0 \\
3.4 \\
3.2 \\
3.9\end{array}$ & Dalenows & 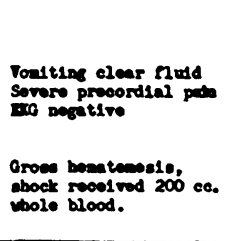 \\
\hline 45 & & & & 2455 & 117 & 12 & 260 & 3.5 & & \\
\hline
\end{tabular}

-L= Lupo-edrimal oortox

A- Aquooun edrenel cortex

CASE IX-E. M. 
46 yoar ald Nogress. Diagnosis-Laemnoc's etrrhosts. Prolonged alcoholtsa. LAver much onlarged and tender. Bromsulphe-

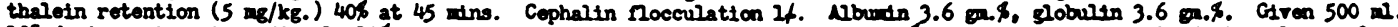
$10 \%$ dextrose in water, $500 \mathrm{ml}$. 105 deatrose in saltno, and $1000 \mathrm{ml}$. feodting of spectal formula contatining $30 \mathrm{mBq}$. Naf. Patient unable to take regular diet or routt futce ndxture. Pariods of romiting during the studs.

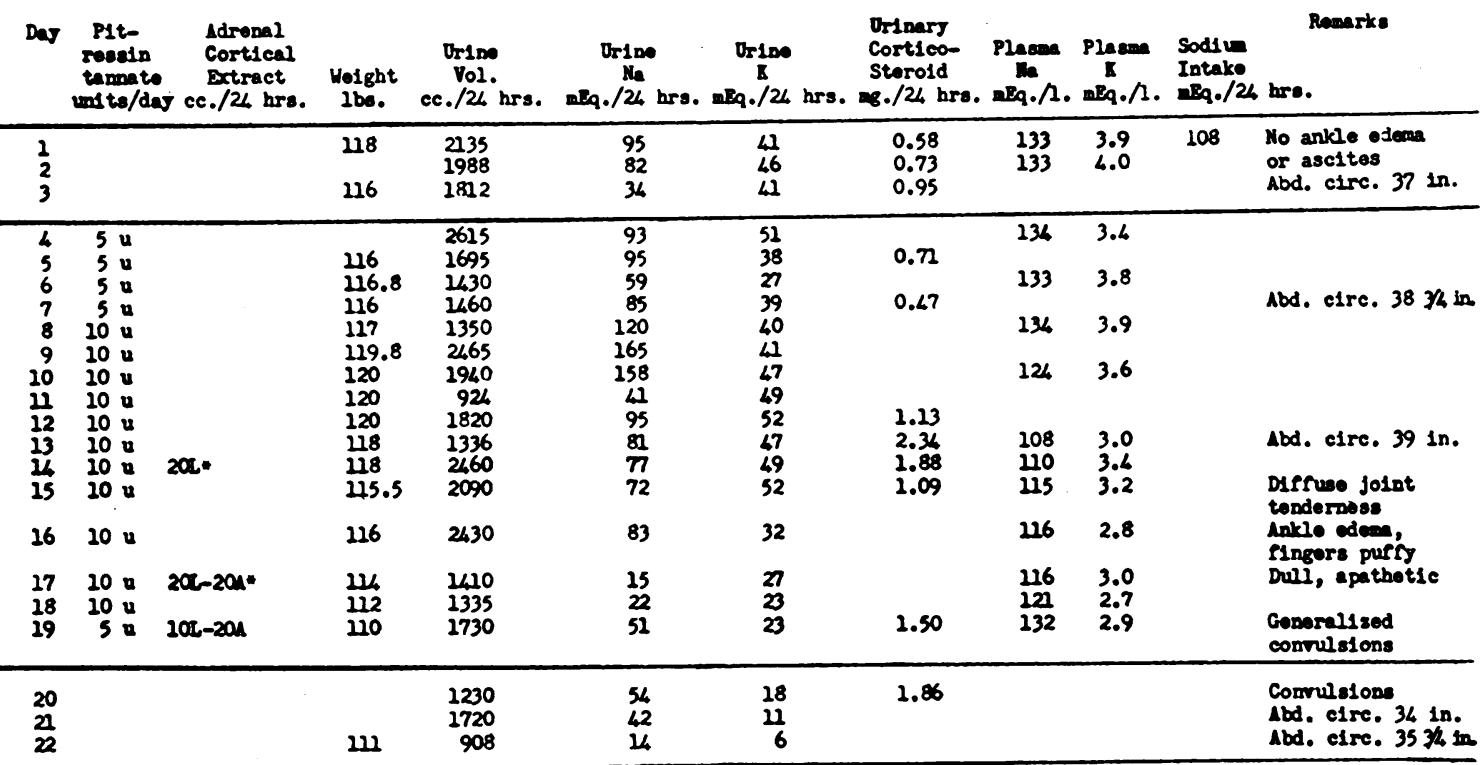

I I I Lipo-adronal cortax

1 - Aqueous adronal cortex

CAsE X-C. M.

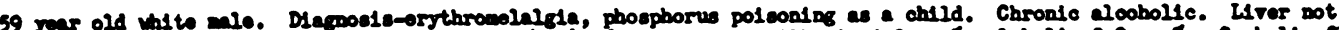

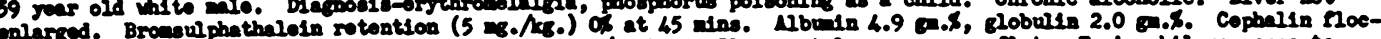

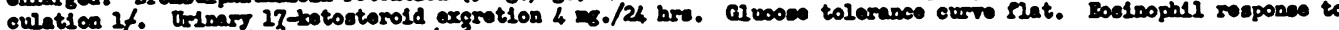
adronelin: basel 88/m, 4 hre. 105/m.

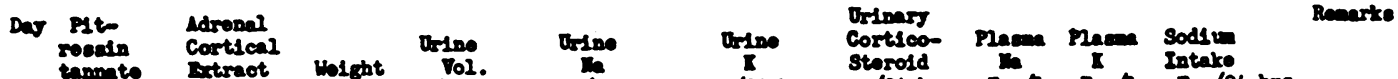

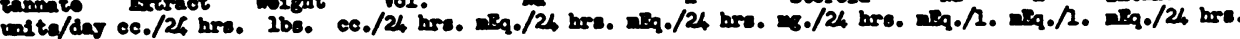

\begin{tabular}{|c|c|c|c|c|c|c|c|c|c|c|}
\hline 1 & & & 109 & 1355 & & & 0.43 & & 90 & If ankle odcen vitb \\
\hline $\begin{array}{l}2 \\
3 \\
\end{array}$ & & & $\begin{array}{l}109 \\
109 \\
\end{array}$ & $\begin{array}{l}1690 \\
1210 \\
\end{array}$ & $\begin{array}{l}62 \\
66 \\
\end{array}$ & $\begin{array}{l}20 \\
25 \\
\end{array}$ & $\begin{array}{l}0.32 \\
0.33 \\
\end{array}$ & 139 & 3.9 & \\
\hline $\begin{array}{l}4 \\
5 \\
6 \\
7 \\
8 \\
9 \\
10 \\
11 \\
12 \\
13 \\
14 \\
15 \\
16 \\
17\end{array}$ & $\begin{array}{ll}5 & u \\
5 & a \\
5 & u \\
5 & u \\
5 & u \\
5 & u \\
5 & u \\
5 & u \\
5 & u \\
5 & u \\
5 & u \\
5 & u \\
5 & u \\
5 & u \\
\end{array}$ & $\begin{array}{l}100-201 " \\
10 z-201 \\
102\end{array}$ & $\begin{array}{l}109 \\
111.8 \\
113 \\
115.5 \\
116 \\
116 \\
107 \\
113 \\
113.5 \\
121.5 \\
109 \\
111 \\
107.5 \\
115\end{array}$ & $\begin{array}{r}590 \\
1385 \\
1200 \\
1395 \\
2510 \\
2300 \\
460 \\
850 \\
1250 \\
2250 \\
620 \\
3575 . \\
670 \\
1085\end{array}$ & $\begin{array}{r}99 \\
189 \\
139 \\
181 \\
35 \\
5 \\
5 \\
39 \\
81 \\
37 \\
51 \\
91 \\
75 \\
196\end{array}$ & $\begin{array}{l}36 \\
38 \\
43 \\
64 \\
70 \\
21 \\
18 \\
26 \\
33 \\
25 \\
17 \\
33 \\
32 \\
36\end{array}$ & $\begin{array}{l}0.52 \\
0.82 \\
1.56 \\
0.86 \\
0.18 \\
\\
0.62 \\
0.52 \\
1.09 \\
0.53\end{array}$ & $\begin{array}{l}139 \\
129 \\
118 \\
120 \\
123 \\
130 \\
125 \\
122 \\
128 \\
136\end{array}$ & $\begin{array}{l}4.0 \\
3.9 \\
4.3 \\
4.2 \\
4.5 \\
4.3 \\
4.3 \\
5.9 \\
4.6 \\
4.5\end{array}$ & 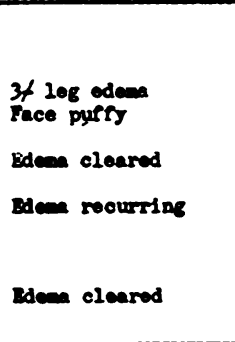 \\
\hline $\begin{array}{l}18 \\
19 \\
20 \\
21 \\
22\end{array}$ & & & $\begin{array}{l}121 \\
110 \\
110 \\
210\end{array}$ & $\begin{array}{l}1890 \\
2125 \\
2120 \\
1620\end{array}$ & $\begin{array}{l}54 \\
22 \\
49 \\
49\end{array}$ & $\begin{array}{l}18 \\
20 \\
42 \\
22\end{array}$ & $\begin{array}{l}0.69 \\
0.49\end{array}$ & $\begin{array}{l}235 \\
138\end{array}$ & $\begin{array}{l}4.5 \\
4.4\end{array}$ & $\begin{array}{l}\text { Bdem rocurring } \\
\text { Edem cleared }\end{array}$ \\
\hline
\end{tabular}




\section{REFERENCES}

1. Gaunt, R., and Birnie, J. H., Hormones and body water. Springfield, Ill., Charles C Thomas, 1951.

2. Corey, E. L., and Britton, S. W., The antagonistic action of desoxycorticosterone and post-pituitary extract on chloride and water balance. Am. J. Physiol., 194t, 133, 511.

3. Lloyd, C. W., and Lobotsky, J., Serum antidiuretic substances and urinary corticosteroid in the human. J. Clin. Endocrinol., 1950, 10, 318.

4. Ralli, E. P., Robson, J. S., Clarke, D., and Hoagland, C. L., Factors influencing ascites in patients with cirrhosis of the liver. J. Clin. Invest., 1945, 24, 316.

5. Heller, H., and Urban, F. F., The fate of the antidiuretic principle of post-pituitary extracts in vivo and in vitro. J. Physiol., 1935, 85, 502.

6. Eversole, W. J., Birnie, J. H., and Gaunt, R., Inactivation of posterior pituitary antidiuretic hormone by the liver. Endocrinology, 1949, 45, 378.

7. Birnie, J. H., Inactivation of posterior pituitary antidiuretic hormone by liver extracts. Federation Proc., 1950, 9, 12.

8. Lloyd, C. W., and Lobotsky, J., Studies of urinary corticosteroid by a method permitting analysis of steroids poorly soluble in water. I. Normal adrenal function. J. Clin. Endocrinol., 1950, 10, 1559.

9. White, A. G., Rubin, G., and Leiter, L., Studies in edema. III. The effect of Pitressin on the renal excretion of water and electrolytes in patients with and without liver disease. J. Clin. Invest., 1951, 30, 1287.

10. Nelson, W. P., III, and Welt, L. G., The effects of
Pitressin on the excretion of water and electrolytes in normal subjects and patients with cirrhosis of the liver and ascites. J. Clin. Invest., 1951, 30, 663.

11. Heller, H., The state in the blood and the excretion by the kidney of the antidiuretic principle of posterior pituitary extracts. J. Physiol., 1937, 89, 81.

12. Birnie, J. H., Jenkins, R., Eversole, W. J., and Gaunt, $R$., An antidiuretic substance in the blood of normal and adrenalectomized rats. Proc. Soc. Exper. Biol. \& Med., 1949, 70, 83.

13. Loewy, E. H., and Lloyd, C. W., Unpublished data.

14. Birnie, J. H., Blackmore, K. E., and Heller, H., Changes in water diuresis and vasopressin inactivation in mice fed on protein deficient diets. Experientia, 1952, 8, 30.

15. Bartter, F., Discussion of Lloyd, C. W., Some clinical aspects of adrenal cortical and fluid metabolism, Recent Progress in Hormone Research, 1952, 7, 508.

16. Dietel, F. G., and Ditsch, H., Uber den Einfluss non Hypophysenhinterlappenextrakt und Thyroxin auf den Wasser-, Natrium- und Chlorgehalt der Gewebe. Klin. Wchnschr., 1934, 13, 1174.

17. Keutmann, E. H., Discussion of Lloyd, C. W., Some clinical aspects of adrenal cortical and fluid metabolism. Recent Progress in Hormone Research, 1952, 7, 508.

18. Overman, R. R., Sodium, potassium and chloride alterations in disease. Physiol. Rev., 1951, 31, 285.

19. Nagareda, C. S., and Gaunt, R., Functional relationship between the adrenal cortex and posterior pituitary. Endocrinology, 1951, 48, 560. 